\title{
3D models related to the publication: Gnathovorax cabreirai: a new early dinosaur and the origin and initial radiation of predatory dinosaurs
}

\author{
Cristian Pacheco ${ }^{1}$, Rodrigo Temp Müller ${ }^{2}$, Max Cardoso Langer ${ }^{3}$, Flávio Pretto ${ }^{1,2}$, Leonardo Kerber ${ }^{1,2 *}$, Sérgio \\ Dias-da-Silva ${ }^{1,2}$ \\ ${ }_{1}^{1}$ Programa de Pós-Graduação em Biodiversidade Animal, Universidade Federal de Santa Maria, Santa Maria, RS, Brazil, CEP 97105-900 \\ ${ }^{2}$ Centro de Apoio à Pesquisa Paleontológica da Quarta Colônia, Universidade Federal de Santa Maria, São João do Polêsine, RS, Brazil, CEP \\ 97230-000 \\ ${ }^{3}$ Laboratório de Paleontologia, Universidade de São Paulo, Ribeirão Preto, SP, Brazil, CEP 14040-900. \\ *Corresponding author: leonardokerber@gmail.com
}

\section{Abstract}

The present 3D Dataset contains the 3D models of the skull, brain and inner ear endocast analyzed in "Gnathovorax cabreirai: a new early dinosaur and the origin and initial radiation of predatory dinosaurs".

Keywords: brain, Dinosauria, endocranial morphology, Herrerasauridae, inner ear.

Submitted:2019-10-03, published online:2019-11-08. https://doi.org/10.18563/journal.m3.103

$\begin{array}{lc}\text { Model IDs } & \text { Description } \\ \text { M3\#442 } & \text { 3D model of the skull } \\ \text { M3\#443 } & \text { 3D model of the braincase } \\ \text { M3\#444 } & \text { Endocast of brain, inner ear, and cranial } \\ & \text { nerves }\end{array}$

Table 1. List of 3D models of Gnathovorax cabrerai from the Upper Triassic (Carnian) of southern Brazil. The original specimen (CAPPA/UFSM 0009) and 3D models belong to the paleontological collection of the Centro de Apoio à Pesquisa Paleontológica da Quarta Colônia, Universidade Federal de Santa Maria.

\section{INTRODUCTION}

Gnathovorax cabreirai is a herrerasaurid dinosaur described based on an exquisite specimen found as part of a multitaxic association form southern Brazil. The type specimen comprises a complete and well-preserved articulated skeleton, preserved in close association (side by side) with rhynchosaur and cynodont remains. Given its superb state of preservation and completeness, the new specimen sheds light into poorly understood aspects of the herrerasaurid anatomy, including endocranial soft tissues. This contribution contains the 3D models of the skull, brain, and inner ear of this early dinosaur (Table 1 and Fig. 1).

\section{METHODS}

The skull of CAPPA/UFSM 0009 (Centro de Apoio à Pesquisa Paleontológica da Quarta Colônia, Universidade Federal de Santa Maria) was scanned with a Philips Brilliance 64-Slice CT Scanner (located at Santa Maria city), using $120 \mathrm{kV}, 150.52 \mathrm{mAs}$. The analysis generated 1002 slices with a $0.67 \mathrm{~mm}$ thickness, increment of $0.33 \mathrm{~mm}$, and pixel size of $0.553 \mathrm{~mm}$. To access the endocranial information of CAPPA/UFSM 0009, its braincase was scanned with a CT scan Skyscan ${ }^{\mathrm{TM}} 1173$ at Laboratório de Sedimentologia e Petrologia of the Pontifícia Universidade
Católica do Rio Grande do Sul (PUCRS), Porto Alegre, Brazil, using $130 \mathrm{kV}$ and $61 \mu \mathrm{A}$. The scan resulted in 2,631 tomographic slices, with a voxel size of $29.98 \mu \mathrm{m}$. Before segmenting the regions of interest, slices without information were deleted, and the remaining files were cropped and binned using the software ImageJ (Abràmoff et al. 2004). After these procedures, the sequence of tomographic slices was limited to 1200 , with a voxel size of $59.96 \mu \mathrm{m}$. The slices were imported in Avizo, the internal cavities were manually segmented, and 3D-models were generated (.stl format). The 3D surface models are provided in .ply format, and can therefore be opened with a wide range of freeware.

\section{ACKNOWLEDGEMENTS}

The authors thanks Valnir de Paula and the medical clinic DIX - Diagnóstico por Imagem do Hospital de Caridade for the allowance to access of the CT-Scan, and the editors of MorphoMuseuM. This study is supported by Coordenação de Desenvolvimento de Pessoal de Nível Superior- Brasil (CAPES) Finance Code 001 (AEBP); Fundação de Amparo à Pesquisa do Estado do Rio Grande do Sul (FAPERGS) 17/2551-0000816-2), and Conselho Nacional de Desenvolvimento Científico (CNPq 422568/2018-0 to LK; 306352/2016-8 to SDS).

\section{BIBLIOGRAPHY}

Abràmoff, M.D., Magalhães, P.J., Ram, S.J. 2004. Image processing with ImageJ. Biophotonic International. 11:36-42.

Pacheco, C., Müller, R.T., Langer, M., Pretto, F., Kerber, L., Dias-da-Silva, S. 2019. Gnathovorax cabreirai: a new early dinosaur and the origin and initial radiation of predatory dinosaurs. Peer J. 7:e7963 http://doi.org/10.7717/peerj.7963 


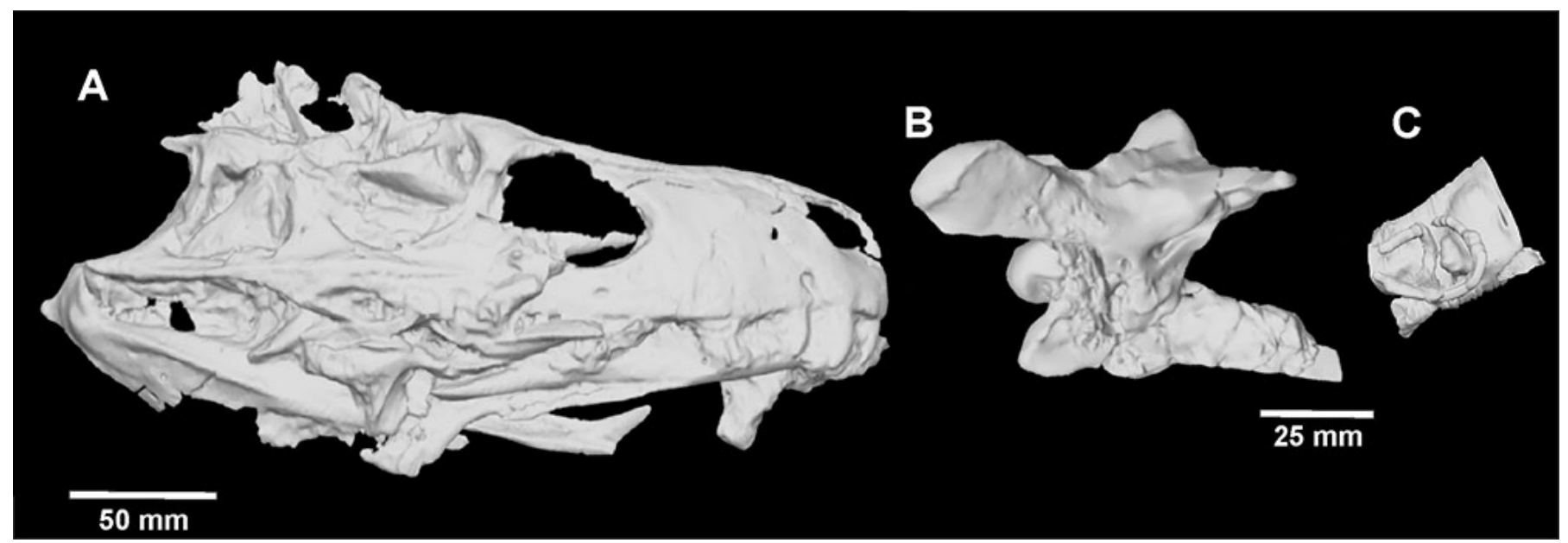

Figure 1. 3D models of the skull (A-B) and endocast of brain, inner ear, and cranial nerves (C) of Gnathovorax cabreirai from the Upper Triassic (Carnian) of southern Brazil. 